Society for the Anthropology of Work • Policing and Labor

\title{
Introduction: Policing and Labor
}

Jessica Katzenstein

Published on: Dec 01, 2020

DOI: $10.21428 / 1 \mathrm{~d} 6$ be30e.e052553e

License: Creative Commons Attribution 4.0 International License (CC-BY 4.0). 
George Floyd's killing in May 2020 catalyzed global public outrage and reignited a slow-burning crisis of U.S. police legitimacy. Legal mechanisms for avoiding murder charges, police unions' political dominance, and omnipresent white supremacy and anti-Black racism all faced broader scrutiny than ever. Meanwhile, harshly imposed lockdowns in other parts of the pandemic-stricken world worsened existing police violence. Officers harassed, beat, and killed already vulnerable people as they enforced regulations in India, Brazil, and multiple European countries. Clearly, the work of policing is imbricated within and often exacerbates the crises of the early twenty-first century. Among critics, police are often seen as an engine and conduit of state violence or else as a spectral power, a "nowhere-tangible, all-pervasive, ghostly presence" (Benjamin 1978: 243). Yet policing is also materialized in forms of labor riven by internal struggles, and its frontline representatives are subject to boredom, precarity, and exploitation. How do we read these aspects together?

I want to suggest that reading policing as work affords fresh insight into the figure of the police at the heart of many urgent political struggles. Whereas critical approaches to police treat the categories of policing and labor as distinct, fields like criminology and criminal justice have generally brought the two concepts together to examine how effectively police work suppresses crime. ${ }^{1}$ This collection pursues a different goal: to explore how approaching policing as work can reveal fissures and tensions within its reproduction of power. Most of the essays focus on low-level police workers, who are both the most visible enforcers of violent logics and, within their organizations, the least responsible for devising violent policies.

Foregrounding the labor of these workers is often taken as an exculpatory endeavor, especially in contemporary U.S. discourse. Scholarship in this vein commonly involves appeals to improve working conditions or to "respect" police work as a noble and sacrificial endeavor. This approach forecloses critical analysis by counterposing questions of labor conditions and officers' vulnerabilities as workers, on the one hand, with structural critiques of policing in relation to state power and global antiBlackness, on the other. Interrogating police work qua work can therefore be read as effecting an ideological rescue of policing projects. By focusing on the mundane textures of frontline labor, one might pass over the primary functions policing serves, the communities it harms, the visions of humanity it reinforces and protects.

This collection takes up such tensions as invitations, not to ideological rescue but rather to critical ethnographic analysis. Within anthropology, ethnographies of work 
have traditionally focused on working-class labor, particularly in industrial sites (Nash 1979; Wolf 1982; Durrenberger 2007; Kasmir and Carbonella 2014), while ethnographies of policing have generally centered themes of governance, order, the law, culture, morality, and reflections on the utility of ethnography (Garriott 2013; Fassin 2017; Karpiak and Garriott 2018b). This collection draws these two modes of study together. It assembles writing from both within and beyond anthropology to investigate how state dominance and racial capitalism are materialized or refigured through police work, whether in the spectacle of the uniformed officer or even the policing power of universities. It charts how we might understand officers' own economic precarities and racialized and gendered vulnerabilities alongside their primary function of enforcing the social order. Finally, it asks about the work that scholars of the police do in analyzing, dismantling, or upholding the violence of policing.

I focus this brief introduction on three major tensions that I see emerging from this collection, both from the essays themselves and from the political moment in which we write, namely: humanization versus critique, the relative centrality of violence, and policing as a global form.

The question of humanization perennially plagues the anthropology of policing (Karpiak and Garriott 2018a), as well as other efforts to study violent, racist, and/or powerful subjects (Nader 1972; Harding 1991). If we theorize the police as both agents of state violence and as workers-as figures who both embody and exceed their structural role, or who are, in other words, human-are we undermining political critique of the police? I certainly witnessed this dynamic in my own fieldwork with U.S. police officers, whom a progressive activist friend once cautioned me not to "humanize them too much." Many officers clearly hoped that I would do precisely this by acting as their translator. They wanted me to explain the material difficulties of their jobs in order to convince a critical public that they are "only human." Instructing people about the struggles of police work was meant to reveal that radical critiques of the institution were misunderstandings of reality. I realized that an analysis of their work as work was, for many police officers, a redemptive political project. 
Many scholars and activists have rightfully challenged an insistence on reading policing as labor under this paradigm, for instance decrying police supporters' demands to recognize the "humanity" of police officers when they routinely refuse to grant that same humanity to their racialized victims. ${ }^{2}$ Indeed, as $\underline{\text { P. Khalil Saucier }}$ reminds us, humanity under modernity has always signified the erasure of Blackness. We can also witness this struggle over redeeming police labor in debates about the limits of worker solidarity with police unions. Labor unions around the world question how security workers can be included in their ranks when these workers act in ways that are antithetical to the well-being of the multiracial working class, as Lior Volinz shows in occupied Jerusalem. This collection strives to reframe the question of humanization by providing new terrain for what Jeffrey_Martin calls the "slow unsettling project of critique." By animating the human and the worker in the police officer, we gain deeper understandings of how police workers are produced, ${ }^{3}$ and the sometimes counterintuitive processes by which they reproduce violent systems.

This leads us to another structuring tension: whether violence is the central mandate and purpose of policing, or merely one of its means. ${ }^{4}$ Locating violence at the core of policing (e.g., Bittner 1990; Seigel 2018) does not necessarily require us to analytically reduce police work to the enactment of violence. Rather, it facilitates a recognition that seemingly disparate police functions, from directing traffic to raiding homes, assume institutional and social coherence under the banner of force. The fact that force remains mostly in potentiality-as the mere threat of state-sanctioned violence in the coiled brutality of the baton-is precisely what lends the police its power. By contrast, some anthropologists of the police have argued for analytically decentering violence (Jauregui 2016; Martin 2019), seeing it as one among a panoply of means toward a diverse set of ends. Framing violence as the heart of policing may obscure other functions police perform.

Does analytically centering violence necessarily prevent us from reckoning with other modes of police work, or even with violence that police officers face themselves? Furthermore, how do we account for the occasions on which police do "protect and serve"? Could we do so without simultaneously reproducing discourses of protection that reinforce police legitimacy? This collection grapples with these questions by attending to encounters where police officers may not successfully project hyperempowerment, and where we instead observe ruptures in police domination. It traces what Ana Ivasiuc calls "dirty work" in policing, which marginalizes its practitioners even as it represses racialized others. It thus seeks, in Pooja Satyogís $\underline{\text { words, }}$ "to gauge the circularity of violence, which builds on templates of social 
exclusion and affords little clarity about whether the police as such are the fountainhead of violence."

A third tension suturing this collection involves fractures in the concept of police work across contexts. The fact that policing takes profoundly variable formations globally is a familiar theme among anthropologists, but it can be obscured in U.S.-focused debates over police reform and abolition. For instance, the illegality of police unions in India stands in stark contrast to U.S. police unions' power to circumscribe the horizons of police accountability. Such distinctions condition officers' relative exploitability and empowerment; they also structure how concepts travel. Calls to defund police may not translate well to locations where police are already relatively underfunded. ${ }^{5}$ Indeed, the very association of police officers with hyperempowerment, and therefore of police work with ultimate coercive power, emerges from situated political histories of power and impunity.

Thus, how we respond to calls to defund or abolish policing depends on the historical and institutional contexts of police work as well. What Paul Clarke calls the "forms of desire and the attendant structures that currently make policing a necessary and sustainable form of labor" take different shapes among precariously employed security workers in South Africa, as his essay explores; Turkish police expanding the reach of their surveillance, as Hayal Akarsu documents; and U.S. police lobbying against civilian oversight, as Theresa Rocha Beardall shows. In short, this collection resists singular notions of police work-or responses to it-that cannot account for the multiplicities of global policing. At the same time, it recognizes the animating threads that cross global boundaries: anti-Blackness, oppression of the poor, and a foundational mandate to uphold unjust social orders.

The collection opens with two essays that reframe questions about the nature of police work. Lachlan Summers and Kathryn Gougelet examine a wildcat strike among graduate student workers at the University of California, Santa Cruz, demonstrating how our own institutions internalize policing logics that enforce academic divisions of labor. P. Khalil Saucier critiques the structuring anti-Blackness of political-economic and antiracist analyses of policing in the Mediterranean, showing how antiracism is itself a form of police work. The second pair of essays asks about the role of violence in 
policing. Jeffrey Martin draws on Hannah Arendt to theorize how police discretion mediates between state violence and the possibilities of political action. Pooja Satyogi investigates the layers of caste-inflected, gendered, and bureaucratic violence operative in pandemic policing in India.

The next set of essays explore the production and subjectivization of police workers. Susana Durão and Wellynton Samuel Oliveira de Souza trace how antifascist police in Brazil strive to produce a new model of the police officer as a self-conscious worker. Tatenda Mangurenje examines African American officers' shifts from idealist aspirations to weaponizing anti-Black respectability politics. Parsa Bastani demonstrates the ways that police in U.S. drug courts reproduce racialized criminalization even as they attempt to counteract it. David Sausdal argues that Danish detectives' callousness toward foreigners emerges from stripping avenues of fun from their workaday lives.

The following three essays examine shifts in police work toward technicized, audited, and digital forms of labor. Kevin Karpiak analyzes how a French model of policing focused on the social was replaced by a "culture of results" focused on assessment and auditing. Tereza Kuldova and Christin Thea Wathne trace how right-wing reforms have pushed Norwegian police away from valuing local knowledge and toward militaristic, quantified forms of labor. Hayal Akarsu examines the "digital hailing" of the Turkish National Police, who use new technologies to perform older modes of police work.

Another set of essays analyzes policing and private security work as only provisionally authoritative (see Jauregui 2016). Lior Volinz analyzes the ideological fault lines and struggles over worker solidarity in the making and unmaking of a private security union in occupied Jerusalem. Ana Ivasiuc shows how the "dirty work" of policing Roma settlements pushes Italian police officers to the bottom of their institutional hierarchy. Sang_lk Song explores the inseparability of policing and health in Canadian hospital security work, where officers embody repressive power while risking their own bodies for medical management.

The final three essays interrogate abolitionist futures. Yutong Han charts the affective labor of U.S. university police officers to argue for incorporating private security into calls to defund the police. Theresa Rocha Beardall lays out how U.S. civilian review boards, an employment infrastructure won through Black and Brown organizing, can be leveraged toward defunding and abolishing the police. Finally, Paul Clarke traces how private security officers in South Africa escape their exploitative jobs, and offers a blueprint for an abolitionist anthropology that imagines a world without police. 


\section{Notes}

1. See Neocleous 2000 and J. Smith and Linnemann 2015 for critiques of these disciplines. Segments of these fields, such as critical criminology, tend to offer more structural analyses.

2. A broader exploration of who is afforded the category of humanity and the politics of reclaiming it-for instance, by circulating images of Black suffering, which usually "function as a hail to the non-Black person" (Sharpe 2016: 116)—is beyond the scope of this essay.

3. See, for instance, Van Maanen 1973 and Beliso-De Jesús 2020 for ethnographies of police training.

4. Here, I mean violence writ large, including the global labor of circulating tools and technics of social control (McCoy 2009; Schrader 2019; Go 2020); the reproduction of racial, colonial, classed, and gendered social orders (Fassin 2013; Gamal 2016; C. Smith 2016; Vitale 2017; Correia and Wall 2018; Seigel 2018); the full spectrum of violence work against the body (Huggins, Haritos-Fatouros, and Zimbardo 2002; see also Ralph 2020); and, broadly, "the cause of premature deaths" (Gilmore 2002: 16), in line with Ruth Wilson Gilmore's (2007: 247) definition of racism as "the statesanctioned or extralegal production and exploitation of group-differentiated vulnerability to premature death."

5. Pooja Satyogi, Tessa Diphoorn, and Marta-Laura Suska made this point in various live-streamed panels at the 2020 "Raising Our Voices" event series.

\section{Acknowledgments}

I would like to thank the board of the Society for the Anthropology of Work, for proposing this collection; Sarah Besky, for suggesting that I edit it and for her consistent and helpful support; Marcel LaFlamme, for his tireless editing work and keen oversight of Exertions; all of the contributors, for their thoughtful essays and their patience throughout the process of assembling this collection; Jeff Martin and the "Raising Our Voices" roundtable participants, for continuing the conversation and coming together virtually amid the pandemic; and Malay Firoz, for his deep engagement, profound insights, and boundless support on this project, as with every other. 


\section{Author Bio}

Jessica Katzenstein is a PhD candidate in the Department of Anthropology at Brown University. Her dissertation interrogates how the everyday labor of policing renders reform into a kind of productive failure, and her research interests include whiteness and racism, violence, labor, and the state. She is currently a Fellow with the Center for Engaged Scholarship.

\section{Preview Image}

Photo by $\underline{\text { Chris Henry. }}$

\section{References}

Beliso-De Jesús, Aisha M. 2020. "The Jungle Academy: Molding White Supremacy in American Police Recruits." American Anthropologist 122(1): 143-56.

Benjamin, Walter. 1978. “Critique of Violence.” In Reflections: Essays, Aphorisms, Autobiographical Writing, edited by Peter Demetz, translated by Edmund Jephcott. New York: Schocken.

Bittner, Egon. 1990. Aspects of Police Work. Boston: Northeastern University Press.

Correia, David, and Tyler Wall. 2018. Police: A Field Guide. New York: Verso.

Durrenberger, E. Paul. 2007. "The Anthropology of Organized Labor in the United States." Annual Review of Anthropology 36: 73-88.

Fassin, Didier. 2013. Enforcing Order: An Ethnography of Urban Policing. Malden, MA: Polity.

ed. 2017. Writing the World of Policing: The Difference Ethnography Makes. Chicago: University of Chicago Press.

Gamal, Fanna. 2016. “The Racial Politics of Protection: A Critical Race Examination of Police Militarization." California Law Review 104(4): 979-1008.

Garriott, William, ed. 2013. Policing and Contemporary Governance: The Anthropology of Police in Practice. New York: Palgrave Macmillan.

Gilmore, Ruth Wilson. 2002. "Fatal Couplings of Power and Difference: Notes on Racism and Geography.”. Professional Geographer 54(1): 15-24. 
. 2007. Golden Gulag: Prisons, Surplus, Crisis, and Opposition in Globalizing California. Berkeley: University of California Press.

Go, Julian. 2020. "The Imperial Origins of American Policing: Militarization and Imperial Feedback in the Early Twentieth Century." American Journal of Sociology 125(5): 1193-1254.

Harding, Susan. 1991. "Representing Fundamentalism: The Problem of the Repugnant Cultural Other." Social Research 58(2): 373-93.

Huggins, Martha K, Mika Haritos-Fatouros, and Philip G Zimbardo. 2002. Violence Workers: Police Torturers and Murderers Reconstruct Brazilian Atrocities. Berkeley: University of California Press.

Jauregui, Beatrice. 2016. Provisional Authority: Police, Order, and Security in India. Chicago: University of Chicago Press.

Karpiak, Kevin G., and William Garriott. 2018a. "Introduction: Disciplines, Fields, and Problems." In The Anthropology of Police, edited by Kevin G. Karpiak and William Garriott. New York: Routledge. , eds. 2018b. The Anthropology of Police. New York: Routledge.

Kasmir, Sharryn, and August Carbonella. 2014. Blood and Fire: Toward a Global Anthropology of Labor. Berghahn Books.

Maanen, John Van. 1973. “Observations on the Making of Policemen." Human Organization 32 (4): 407-18.

Martin, Jeffrey T. 2019. Sentiment, Reason, and Law: Policing in the Republic of China on Taiwan. Ithaca, NY: Cornell University Press.

McCoy, Alfred W. 2009. Policing America's Empire: The United States, the Philippines, and the Rise of the Surveillance State. Madison: University of Wisconsin Press.

Nader, Laura. 1972. "Up the Anthropologist: Perspectives Gained from Studying Up.” In Reinventing Anthropology, edited by Dell Hymes, 284-311. New York: Pantheon Books.

Nash, June. 1979. We Eat the Mines and the Mines Eat Us: Dependency and Exploitation in Bolivian Tin Mines. New York: Columbia University Press. 
Neocleous, Mark. 2000. The Fabrication of Social Order: A Critical Theory of Police Power. London: Pluto Press.

Ralph, Laurence. 2020. The Torture Letters: Reckoning with Police Violence. Chicago: University of Chicago Press.

Schrader, Stuart. 2019. Badges without Borders: How Global Counterinsurgency Transformed American Policing. Oakland: University of California Press.

Seigel, Micol. 2018. Violence Work: State Power and the Limits of Police. Durham, NC: Duke University Press.

Sharpe, Christina. 2016. In the Wake: On Blackness and Being. Durham, NC: Duke University Press.

Smith, Christen. 2016. Afro-Paradise: Blackness, Violence, and Performance in Brazil. Urbana: University of Illinois Press.

Smith, Justin, and Travis Linnemann. 2015. "Whiteness and Critical White Studies in Crime and Justice." Contemporary Justice Review: Issues in Criminal, Social, and Restorative Justice 18(2): 101-104.

Vitale, Alex S. 2017. The End of Policing. New York: Verso.

Wolf, Eric. 1982. Europe and the People without History. Berkeley: University of California Press. 